\title{
Application of chlorine dioxide for disinfection of student health centers
}

\author{
Ching-Shan Hsu • Ming-Chun Lu • Da-Ji Huang
}

Received: 11 December 2010 / Accepted: 10 March 2011 / Published online: 1 April 2011

(C) The Author(s) 2011. This article is published with open access at Springerlink.com

\begin{abstract}
In Taiwan, the immediate health care requirements of students and faculty members are satisfied by on-campus medical service centers. The air quality within these centers should comply with the guidelines laid down by the Taiwan Environmental Protection Agency (EPA). Accordingly, this study performed an experimental investigation into the efficiency of various chlorine dioxide applications in disinfecting a local student health center (SHC). The air quality before and after disinfection were evaluated in terms of the bioaerosol levels of bacteria and fungi. The average background levels of bacteria and fungi before disinfection were found to be $1,142 \pm 455.4 \mathrm{CFU} / \mathrm{m}^{3}$ and $520 \pm 442.4 \mathrm{CFU} / \mathrm{m}^{3}$, respectively. Chlorine dioxide $\left(0.3 \mathrm{mg} / \mathrm{m}^{3}\right)$ was applied using three different methods, namely a single, one-off application, multiple applications within a single day, and regular (daily) applications. Among the three disinfection methods, the regular application method was found to yield a high disinfection efficiency for both bacteria and fungi, i.e., $6.5 \pm 0.7 \%$ and $4.2 \pm 0.3 \%$, respec-
\end{abstract}

C.-S. Hsu ( $\varangle)$ · M.-C. Lu · D.-J. Huang

Department of Environmental Resource

Management, Chia-Nan University of Pharmacy

and Science, Tainan 71710, Taiwan

e-mail: hsuhsu@mail.chna.edu.tw tively. The average residual bacteria and fungi levels after regular daily interval disinfection were $318.8 \pm 51.5 \mathrm{CFU} / \mathrm{m}^{3}$ and $254.0 \pm 43.8 \mathrm{CFU} / \mathrm{m}^{3}$, respectively. Therefore, the results suggest that the air quality guidelines prescribed by the Taiwan EPA for SHCs and other healthcare facilities can best be achieved by applying chlorine dioxide at regular (daily) intervals.

Keywords Student health center • Chlorine dioxide $\cdot$ Bioaerosols $\cdot$ Bacteria $\cdot$ Fungi

\section{Introduction}

The term "bioaerosols" refers to microorganisms, particles, gases, vapors, or fragments of biological origin (either alive or released from a living organism) which exist in the air (Berghofer et al. 2003; Kodama and McGee 1986; Brasel et al. 2005; Mitchell et al. 2007). Research has shown that prolonged exposure to bioaerosols in indoor environments may lead to infectious disease, sick building syndrome, or organic dust toxic syndrome (Sanchez et al. 1987). Furthermore, elevated levels of particulate air pollution are associated with decreased lung function, increased respiratory symptoms such as coughing, shortness of breath, wheezing and asthma attacks, as well as chronic obstructive pulmonary disease, cardiovascular disease, and lung cancer (WHO 2002). As a 
result, exposure to bioaerosols in the workplace has been a subject of growing concern in recent years (Orsini et al. 2002; Adhikari et al. 2004; Jones and Harrison 2004).

In non-industrial indoor environments, the principal source of airborne bacteria is the presence of humans and related activities such as talking, sneezing, coughing, walking, washing, and toilet flushing (Stetzenbach 1997). Thus, while indoor environments are supposed to be protective, they can in fact become contaminated with particles which present different and sometimes more serious risks than those in outdoor environments if their concentration levels exceed recommended safety limits. According to the National Institute of Occupational Safety and Health in America and the American Conference of Governmental Industrial Health (ACGIH), the total number of bioaerosol particles in indoor environments should not exceed 1,000 CFUs $/ \mathrm{m}^{3}$, while the total culturable count for bacteria should be not higher than $500 \mathrm{CFUs} / \mathrm{m}^{3}$ (ACGIH 1986, 1989; AIHA 1996). In Taiwan, the indoor air quality should conform to the guidelines prescribed by the Environmental Protection Agency (EPA) (Ling et al. 2008). For schools, educational facilities, playgrounds, hospitals, clinics, and healthcare facilities for older citizens and the disabled, the indoor bacteria concentration should be not higher than $500 \mathrm{CFU} / \mathrm{m}^{3}$, while that of fungi should not exceed 1,000 CFU $/ \mathrm{m}^{3}$ (Taiwan EPA 2005). However, Taiwan lies in a subtropical zone, and is usually warm and humid throughout the entire year. As a result, the local climate is highly conducive to the growth of bioaerosols (Tasi and Liu 2009). According to the results of one long-term monitoring study, the concentration of biological contamination in Taiwan is much higher than the value of $1,000 \mathrm{CFU} / \mathrm{m}^{3}$ recommended by the WHO (Lin et al. 2007). Thus, to satisfy the EPA guidelines for the air quality in indoor environments, effective disinfection treatments are required.

In Taiwan, the immediate health care requirements of students and faculty members are satisfied by on-campus medical service centers. Student health centers (SHCs) are characterized by a high level of human activity and are conducive to the generation and propagation of a large number of bioaerosols by their very nature. As a result, stringent disinfection protocols are required to ensure the health and general well-being of the center's occupants. As in most healthcare facilities around the world, disinfection of the SHCs in Taiwan is accomplished using chlorine dioxide $\left(\mathrm{ClO}_{2}\right) \cdot \mathrm{ClO}_{2}$ can destroy all manner of microorganisms, including bacteria, spores, fungi, viruses, and even protozoans (Taylor and Butler 1982; Chen and Vaughn 1990; Sivaganesan et al. 2003; Loret et al. 2005; $\mathrm{Lu}$ et al. 2004). $\mathrm{ClO}_{2}$ dissolves readily in water, forming a stable state of small particles. $\mathrm{ClO}_{2}$ has strong oxidizability, and therefore exists virtually entirely in a molecular state following application. As a consequence, it readily penetrates and destroys the cell membranes of bacteria. The loss of the cell membrane suppresses respiration in the bacterium body and renders the phosphotransferase mechanism inactive. As a consequence, the bacterium dies (Huang et al. 1997; Li and Kuo 1992; US OSHA 2006). Under room temperature conditions, the $\mathrm{ClO}_{2}$ content within the water evaporates and propagates naturally through the local environment, providing a disinfection function. In a study performed by the US Environmental Protection Agency, it was shown that $\mathrm{ClO}_{2}$ results in no physiologically relevant alterations in human health provided that it is present only in low concentrations (i.e., sub-toxic levels) (US EPA 2000; Wilson et al. 2005).

In a previous study by the present group (Hsu et al. 2010), it was shown that multiple and regular $\mathrm{ClO}_{2}$ applications yielded short-term (4-8 h) disinfection efficiencies of more than $59.0 \%$ in a local SHC in Taiwan. However, the longerterm disinfection efficiency was not considered. The present study performed a more detailed investigation, in which the sampling time following disinfection was increased to $12 \mathrm{~h}$, and factors such as the number of people within the SHC, the temperature, and the relative humidity were also taken into account. As in the previous study, three different $\mathrm{ClO}_{2}$ fumigation procedures were performed, namely single, multiple, and regular. The air quality in the SHC before and after $\mathrm{ClO}_{2}$ disinfection was evaluated in terms of the bioaerosol levels of bacteria and fungi. The air quality results were then analyzed in order to determine the relative disinfection efficiencies of the three different methods. 


\section{Materials and methods}

The study was conducted in the SHC at ChiaNan University, Taiwan. Prior to disinfection, air samples were collected and analyzed in order to determine the background concentration levels of bacteria and fungi. $\mathrm{ClO}_{2}$ disinfection was then carried out using three different application procedures. On each sampling day, air samples were collected over a $12-\mathrm{h}$ period in order to evaluate the reduction in the bacteria and fungi concentration levels. The details of the experimental procedure are described in the sections below.

\section{Study area and sampling time}

Figure 1 presents the floor plan of the SHC considered in the present study. According to the original blueprints, the SHC has a volume of $450 \mathrm{~m}^{3}$. As shown, sampling was conducted in a single location within the SHC. The experimental investigation was conducted over a period of 6 months (June-November, 2009). On each sampling day, samples were collected between the hours of 8:00 am and 8:00 pm. Each time an air sample was collected, the relative humidity and temperature in the SHC were recorded using a TES-1364 Humidity Temperature Meter (TES Corp., Taiwan). In addition, a note was made of the number of individuals present within the SHC at the time.

\section{Disinfection methods}

According to the Occupational Safety and Health Administration (OSHA) of the USA and the American Conference of Governmental Industrial Health, the 8-h time-weighted average (TWA) of $\mathrm{ClO}_{2}$ in the workplace should not exceed $0.3 \mathrm{mg} / \mathrm{m}^{3}$ (equivalent to $0.1 \mathrm{mg} / \mathrm{L}$ ) (US OSHA 2006). Meanwhile, the 15-min shortterm exposure limit of $\mathrm{ClO}_{2}$ should not exceed $0.9 \mathrm{mg} / \mathrm{m}^{3}$ (equivalent to $0.3 \mathrm{mg} / \mathrm{L}$ ). Both limits are required to protect workers against the risk of skin and eye irritation or respiratory disease (Liou and Lai 2003). As stated above, the SHC had a volume of $450 \mathrm{~m}^{3}$. Thus, to satisfy the 8 -h TWA limit of $0.3 \mathrm{mg} / \mathrm{m}^{3}$, fumigation was performed using a $540-\mathrm{mL} \mathrm{ClO}_{2}$ solution $(250 \mathrm{mg} / \mathrm{L})$.

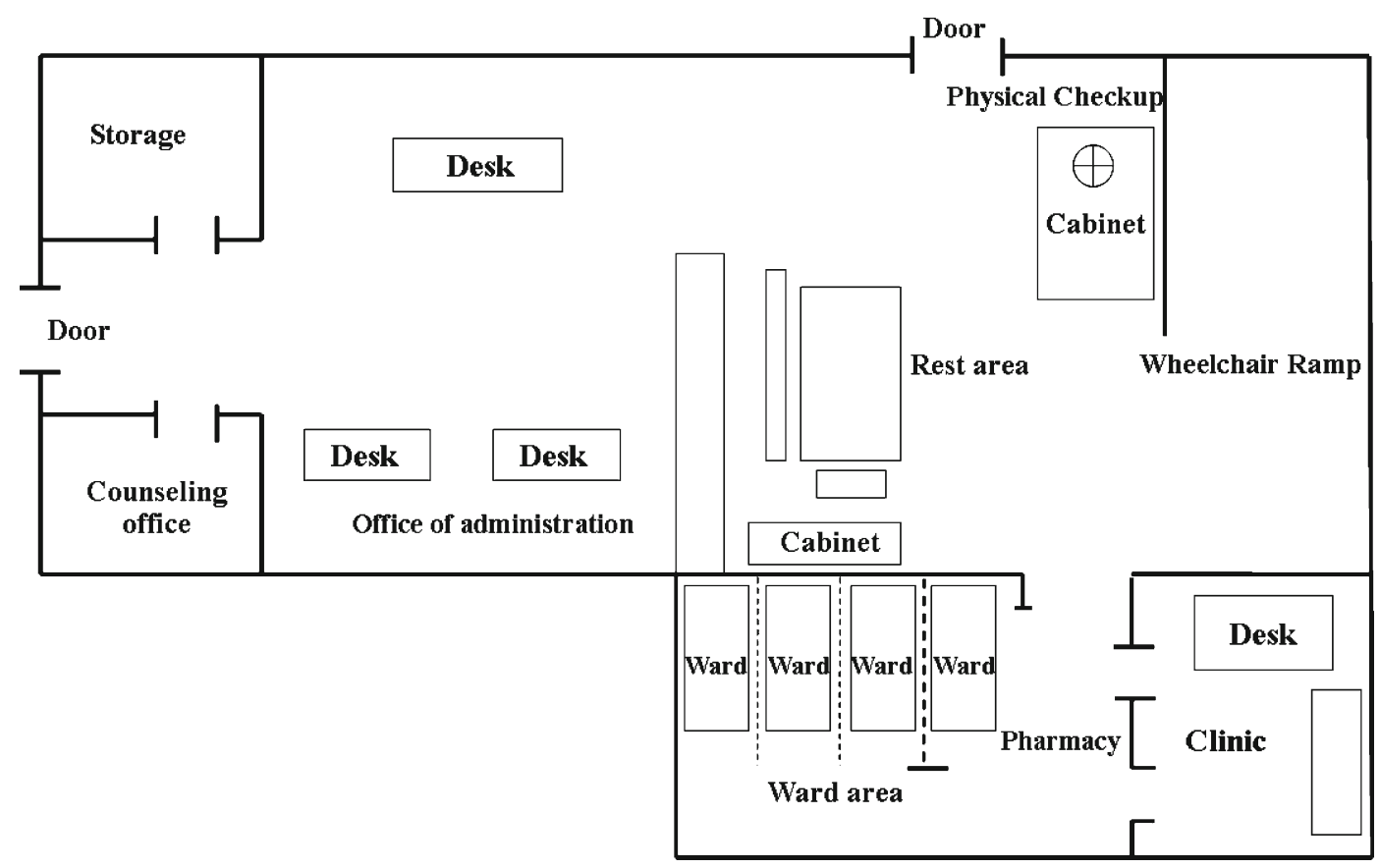

Fig. 1 Floor plan of SHC in Chia-Nan University of Pharmacy and Science, Taiwan. (Circled plus sample location) 
Three different disinfection modes were considered, namely a single application mode (SAM), a multiple application mode (MAM), and a regular application mode (RAM). In the SAM mode, the $540 \mathrm{~mL} \mathrm{ClO}_{2}$ solution $(250 \mathrm{mg} / \mathrm{L})$ was applied for 1 day only, and was not replenished as it evaporated, the experimental investigations were conducted in June and September. In the MAM mode, the $540 \mathrm{~mL} \mathrm{ClO}_{2}$ solution $(250 \mathrm{mg} / \mathrm{L})$ was also applied for 1 day only, but was replenished every $4 \mathrm{~h}$, the experimental investigations were conducted in July and October. Finally, in the RAM mode, the $540 \mathrm{~mL} \mathrm{ClO}_{2}$ solution $(250 \mathrm{mg} / \mathrm{L})$ was applied once a day (without replenishment) for five consecutive days, the experimental investigations were conducted in August and November.

\section{Air sample collection}

Air samples with a volume of 1,0001 were collected before and after $\mathrm{ClO}_{2}$ fumigation in accordance with the Taiwan NIEA Guidelines (NIEA E301.11C and E401.11C for bacteria and fungi, respectively) (Taiwan EPA 2008). The samples were collected using a MAS-100 Eco Microbial Air Sampler (Merck, Germany; 100 L/min). Following a collection time of $10 \mathrm{~min}$, the Petri dishes were extracted from the sampler in order to cultivate the bioaerosols. For the bacteria bioaerosols, the Tryptic Soy Agar plates were incubated at a temperature of $30 \pm 1^{\circ} \mathrm{C}$ for $48 \pm 2 \mathrm{~h}$. Meanwhile, for the fungi bioaerosols, the malt extract agar plates were incubated at $25 \pm 1^{\circ} \mathrm{C}$ for $4 \pm 1$ days. The background concentration levels of bacteria and fungi were then evaluated by counting the colonies formed on the respective agar surfaces.

\section{Statistical analysis}

Significant differences among the disinfection efficiencies of the three $\mathrm{ClO}_{2}$ application proce- dures, were evaluated by means of the Duncan analysis of variance test (ANOVA, $\alpha=0.05$; SPSS Inc., USA 2003).

\section{Results and discussion}

As described in the previous section, the relative humidity, temperature, and number of individuals present in the SHC were recorded each time an air sample was collected. The corresponding results are presented in Table 1. As shown, for the SAM, MAM, and RAM application methods, the average temperature was $26.2 \pm 0.7^{\circ} \mathrm{C}$, $26.5 \pm 3.3^{\circ} \mathrm{C}$, and $26.2 \pm 0.4^{\circ} \mathrm{C}$, respectively, the relative humidity was $53.6 \pm 6.8 \%, 53.1 \pm 5.1 \%$, and $53.5 \pm 0.4 \%$, respectively, and the number of SHC occupants was $8.7 \pm 5.1,7.4 \pm 3.6$, and $6.8 \pm 3.6$, respectively. A one-way ANOVA test was performed to test for significant differences among the average temperature, relative humidity, and number of SHC occupants in the three different application methods. Moreover, a correlation analysis was performed to investigate the relationship among the temperature, relative humidity, and number of SHC occupants. The results of the ANOVA test showed that there were no significant differences among the temperature, relative humidity, and number of SHC occupants in the SAM, MAM, and RAM application methods $(p>0.05)$. Moreover, no significant relationship was observed among the three environmental conditions for the three different methods.

As shown in Figs. 2 and 3, the average bacteria and fungi concentrations in the SHC prior to disinfection were $1,142 \pm 455.4 \mathrm{CFU} / \mathrm{m}^{3}$ and $520.0 \pm 442.4 \mathrm{CFU} / \mathrm{m}^{3}$, respectively. The average bacteria concentration is higher than the recommended level (i.e., $500 \mathrm{CFU} / \mathrm{m}^{3}$ ). The average fungi concentration is less than the maximum permissible level prescribed by the Taiwan EPA (i.e., $1,000 \mathrm{CFU} / \mathrm{m}^{3}$ ) (Taiwan EPA 2005). Figures 2 and
Table 1 Temperature, humidity, and number of occupants in SHC

\begin{tabular}{llll}
\hline Disinfection method & $\begin{array}{l}\text { Temperature } \\
\left({ }^{\circ} \mathrm{C}\right)\end{array}$ & $\begin{array}{l}\text { Relative humidity } \\
(\%)\end{array}$ & $\begin{array}{l}\text { No. of occupants } \\
\text { in SHC }\end{array}$ \\
\hline Single application & $26.2 \pm 0.7$ & $53.6 \pm 6.8$ & $8.7 \pm 5.1$ \\
Multiple applications & $26.5 \pm 3.3$ & $53.1 \pm 5.1$ & $7.4 \pm 3.6$ \\
Regular applications & $26.2 \pm 0.4$ & $53.5 \pm 0.4$ & $6.8 \pm 3.6$ \\
\hline
\end{tabular}




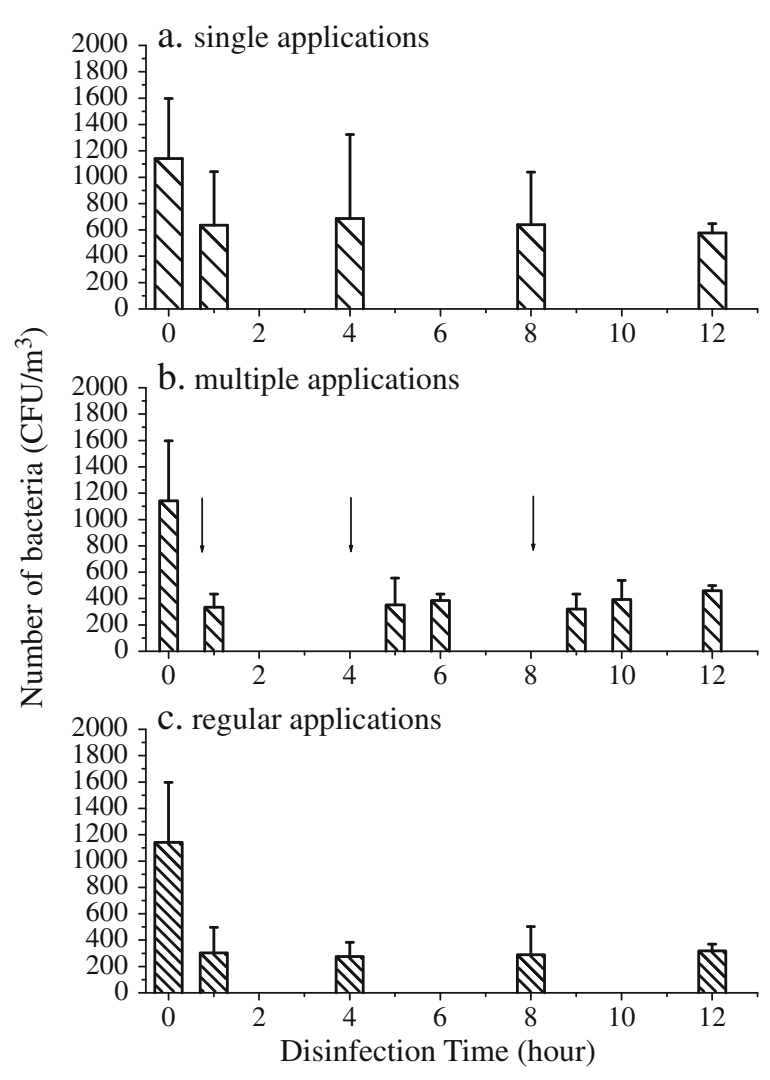

Fig. 2 a-c Impact of three disinfection modes on indoor bacteria bioaerosol concentration (downwards arrow addition of $\mathrm{ClO}_{2}$ )

3 show the average bacteria and fungi concentration levels in the SHC following the three $\mathrm{ClO}_{2}$ applications. The bacteria and fungi disinfection efficiencies of the three application methods are summarized in Table 2. The disinfection per hour was determined to get the average disinfection for comparing the average disinfection efficiency of the three methods in this study. As shown, the SAM, MAM, and RAM application methods result in $5.8 \pm 0.4 \%, 5.8 \pm 0.1 \%$, and $6.5 \pm 0.7 \%$ bacterium disinfections per hour, respectively, and $4.8 \pm 0.8 \%, 4.1 \pm 0.5 \%$, and $4.2 \pm 0.5 \%$ fungi disinfections. According to the results of the Duncan ANOVA test, the residual bacteria level following SAM disinfection is significantly higher than that following the MAM or RAM treatments $(p<$ $0.05)$. However, there is no significant difference among the three different treatment methods in the residual fungi level. The results presented in
Figs. $2 b$ and $3 b$ show that the multiple application treatment reduces both the bacteria and the fungi bioaerosols to acceptable levels. Figure $2 \mathrm{c}$ show that the RAM application method also reduces the residual bacteria concentration levels to a value compatible with the EPA guidelines.

As shown in Table 2, the SAM, MAM, and RAM application methods result in $49.5 \%, 59.8 \%$, and $72.1 \%$ total bacterium disinfections per day, respectively, and $55.1 \%, 50.7 \%$, and $51.1 \%$ fungi disinfections. The results presented in Figs. $2 \mathrm{~b}$ and $3 \mathrm{~b}$ show that the multiple application treatment reduces both the bacteria and the fungi bioaerosols to acceptable levels. Figure $2 \mathrm{c}$ show that the RAM application method also reduces the residual bacteria concentration levels to a value compatible with the EPA guidelines.

Comparing the results presented in Table 2 for the three $\mathrm{ClO}_{2}$ application methods, it is seen that

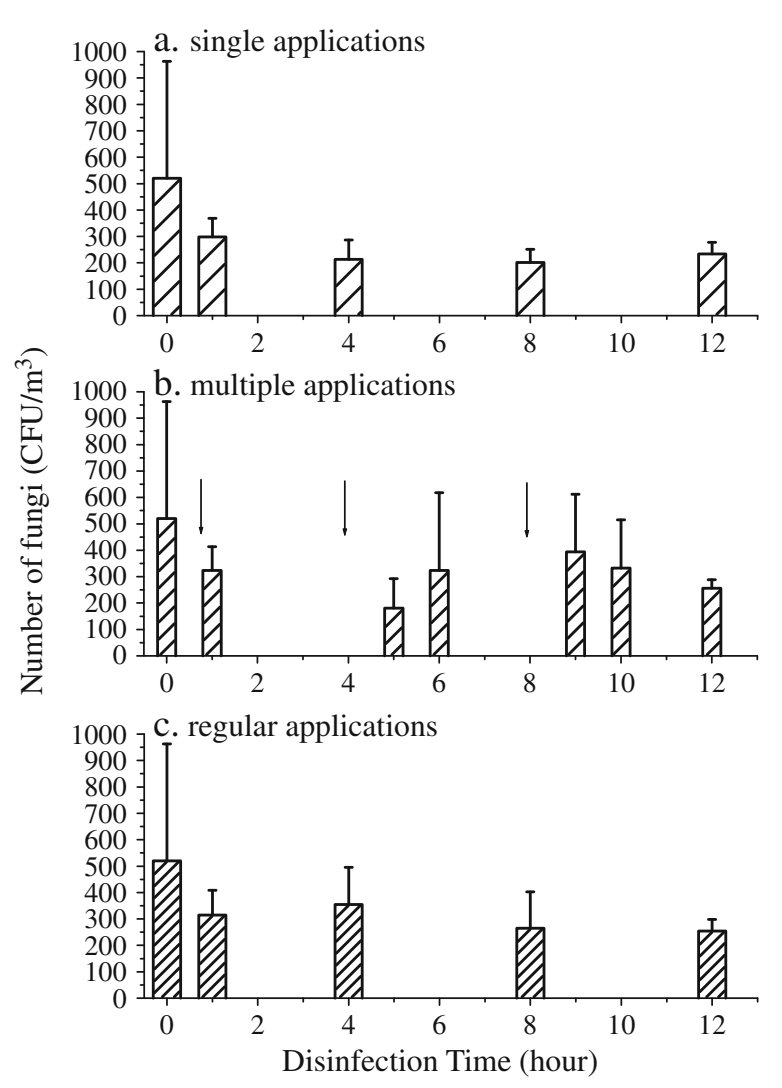

Fig. 3 a-c Impact of three disinfection modes on indoor fungi bioaerosol concentration (downwards arrow addition of $\mathrm{ClO}_{2}$ ) 
Table 2 Disinfection efficiencies of three treatment methods for bacteria and fungi bioaerosols

\begin{tabular}{|c|c|c|c|c|c|c|}
\hline Disinfection method & $\begin{array}{l}\text { Disinfected } \\
\text { bacteria } \\
\text { per hour (\%) }\end{array}$ & $\begin{array}{l}\text { Disinfected } \\
\text { fungi } \\
\text { per hour (\%) }\end{array}$ & $\begin{array}{l}\text { Residual } \\
\text { bacteria } \\
\left(\mathrm{CFU} / \mathrm{m}^{3}\right)\end{array}$ & $\begin{array}{l}\text { Total } \\
\text { disinfected } \\
\text { bacteria (\%) }\end{array}$ & $\begin{array}{l}\text { Residual } \\
\text { fungi } \\
\left(\mathrm{CFU} / \mathrm{m}^{3}\right)\end{array}$ & $\begin{array}{l}\text { Total } \\
\text { disinfected } \\
\text { fungi }(\%)\end{array}$ \\
\hline Single application & $5.8 \pm 0.4$ & $4.8 \pm 0.8$ & $577.1 \pm 69.3^{\mathrm{a}}$ & 49.5 & $233.3 \pm 44.1$ & 55.1 \\
\hline Multiple applications & $5.8 \pm 0.1$ & $4.1 \pm 0.5$ & $459.3 \pm 39.1^{b}$ & 59.8 & $256.4 \pm 32.0$ & 50.7 \\
\hline Regular applications & $6.5 \pm 0.7$ & $4.2 \pm 0.3$ & $318.8 \pm 51.5^{\mathrm{b}}$ & 72.1 & $254.0 \pm 43.8$ & 51.1 \\
\hline
\end{tabular}

${ }^{\mathrm{a}, \mathrm{b}}$ Within the same column, entries annotated with different superscripts exhibit a statistical difference according to Duncan ANOVA test $(p<0.05)$

the single application method yields the poorest disinfection efficiency, while the regular application method results in the highest disinfection efficiency. Figure 2 show that the EPA guidelines for the indoor air quality in medical centers can be achieved using either the MAM method or the RAM method. However, an inspection of Table 2 reveals that the overall disinfection efficiency of the RAM method is slightly higher than that of the MAM method. Furthermore, the RAM method involves fewer daily $\mathrm{ClO}_{2}$ applications, and is therefore more convenient. Thus, the present results suggest that regular (i.e., daily) application of $\mathrm{ClO}_{2}$ represents the most efficient and practical means of satisfying the Taiwan EPA guidelines for the air quality in SHCs in Taiwan.

\section{Conclusion}

This study has performed an experimental investigation into the effectiveness of $\mathrm{ClO}_{2}$ as a disinfection agent for student health centers in Taiwan. Three different $\mathrm{ClO}_{2}$ application methods have been considered, namely a single treatment, multiple treatments at 4-h intervals, and regular (i.e., daily) treatments. In every case, disinfection was performed using $0.3 \mathrm{mg} / \mathrm{m}^{3}$ of $\mathrm{ClO}_{2}$, and the $\mathrm{ClO}_{2}$ was allowed to evaporate and propagate naturally through the air. The experimental results have shown that the multiple treatment method and the regular treatment method both reduce the residual bacteria and fungi concentrations to a level consistent with the guidelines issued by the Taiwan EPA (i.e., $500 \mathrm{CFU} / \mathrm{m}^{3}$ and $1,000 \mathrm{CFU} / \mathrm{m}^{3}$, respectively). In the former method, the $\mathrm{ClO}_{2}$ should be replenished on a fourhourly basis. However, in the latter method, the
$\mathrm{ClO}_{2}$ need be replaced only once a day. Moreover, the disinfection efficiency of the latter method is slightly higher than that of the former. As a consequence, the experimental results suggest that the regular $\mathrm{ClO}_{2}$ treatment process is the most effective and practical means of satisfying the Taiwan EPA guidelines for the indoor air quality in SHCs and similar healthcare facilities.

Acknowledgement This research was supported by the National Science Council of Taiwan under Grant No. NSC97-2622-E-041-002-CC3).

Open Access This article is distributed under the terms of the Creative Commons Attribution Noncommercial License which permits any noncommercial use, distribution, and reproduction in any medium, provided the original author(s) and source are credited.

\section{References}

ACGIH (1986). Guidelines for assessment of bioaerosols in the indoor environment. Cincinnati: American Conference of Governmental Industrial Hygienists.

ACGIH (1989). Guidelines for assessment of bioaerosols in the indoor environment. Cincinnati: American Conference of Governmental Industrial Hygienists.

Adhikari, A., Sen, M. M., Gupta-Bhattacharya, S., \& Chanda, S. (2004). Volumetric assessment of airborne fungi in two sections of a rural indoor dairy cattle shed. Environment International, 29, 1071-1078.

AIHA (1996). Field guide for the determination of biological contaminants in environmental samples. Fairfax: AIHA Press.

Berghofer, L. K., Hocking, A. D., Miskelly, D., \& Jansson, E. (2003). Microbiology of wheat and flour milling in Australia. International Journal of Food Microbiology, 85, 137-149.

Brasel, T. L., Martin, J. M., Carriker, C. G., Wilson, S. C., \& Straus, D. C. (2005). Detection of airborne Stachybotrys chartarum macrocyclic trichothecene mycotoxins on particulates smaller than Conidia. Applied and Environmental Microbiology, 71, 7376-7388. 
Chen, Y. S., \& Vaughn, J. M. (1990). Inactivation of human and simian rotaviruses by chlorine dioxide. Applied and Environmental Microbiology, 56, 1363-1366.

Hsu, C. S., Huang, D. J., \& Lu, M. C. (2010). Improvement on the air quality of student health centers with chlorine dioxide. International Journal Environmental Health Research, 20(2), 115-127.

Huang, J. L., Wang, L., Ren, N. Q., Ma, F., \& Juli (1997). Disinfection effect of chlorine dioxide bacteria in water. Water Research, 33(3), 607-613.

Jones, A. M., \& Harrison, R. M. (2004). The effects of meteorological factors on atmospheric bioaerosol concentrations. Science of the Total Environment, 326, 151-180.

Kodama, A. M., \& McGee, R. I. (1986). Airborne microbial contaminants in indoor environments, naturally ventilated and air conditioned homes. Archives of Environmental Health, 41, 306-311.

Li, C. S., \& Kuo, Y. M. (1992). Airborne characterization of fungi indoors and outdoors. Journal of Aerosol Science, 23(1), 667-670.

Lin, K. S., Hsieh, M. J., Liou, M. J., Liou, M. J., Lee, S. L., \& Lai, C. K. (2007). Disinfection effect of chlorine dioxide on air quality control in Armed Forces General Hospital of Taiwan. Nature and Science, 5(4), 94-99.

Ling, I. M., Lu, M. C., \& Hsu, C. S. (2008). Environmental quality improvement on indoor swimming pools by application of chlorine dioxide. Fresenius Environment Bulletin, 17(8b), 1014-1021.

Liou, M. J., \& Lai, C. G. (2003). Study of chlorine dioxide and by-products formation by electrochemistry technology. Taiwan EPA Environmental Quarterly, 48, 16-23.

Loret, J. F., Robert, S., Thomas, V., Cooper, A. J., McCoy, W. F., \& Levi, Y. (2005). Comparison of disinfectants for biofilm, protozoa and Legionella control. Journal of Water and Health, 3, 423-433.

Lu, M. C., Liu, M. T., Lai, C. K., Lou, C. P., \& Wu, S. B. (2004). Study of disinfection efficiency on air borne bacteria in hospitals by application of chlorine dioxide. In The 17th environmental planning and management seminar, National Cheng Kung University, Taiwan (pp. 223-228).

Mitchell, C. S., Zhang, J., Sigsgaard, T., Jantunen, M., Lioy, P. J., Samson, R., et al. (2007). Current state of the science: Health effects and indoor environmental quality. Environmental Health Perspectives, 115(6), 958-964.
Orsini, M., Laurent, I. P., Boninti, F., Arzani, D., \& Ianni, A. (2002). A molecular typing approach for evaluating bioaerosol exposure in wastewater treatment plant workers. Water Research, 36, 13751378.

OSHA (2006). Occupational safety and health guideline for chlorine dioxide. http://www.osha.gov/SLTC/ healthguidelines/chlorinedioxide/recognetion.html.

Sanchez, D. C., Mason, M., \& Norris, C. (1987). Methods and results of characterization of organic emissions from indoor material. Atmospheric Environment, 21, 337-345.

Sivaganesan, M., Rice, E. W., \& Marinas, B. J. (2003). A Bayesian method of estimating kinetic parameters for the inactivation of Cryptosporidium parvum oocysts with chlorine dioxide and ozone. Water Research, 37, 4533-4543.

Stetzenbach, L. D. (1997). Manual of environmental microbiology. Washington: ASM Press.

Taiwan EPA (2005). Guidelines on indoor air quality. Taiwan Environmental Protection Agency. Available online at http://www.indoorair.org.tw/. Accessed on 05 December 2009.

Taiwan EPA (2008). Guidelines on environmental analysis laboratory EPA. Taiwan Environmental Protection Agency. Available online at http://www.niea.gov.tw/ analysis/method/ListMethod.asp? methodtype=LIVE. Accessed 05 December 2009.

Tasi, Y. M., \& Liu, H. M. (2009). Exposure to culturable airborne bioaerosols during noodle manufacturing in central Taiwan. Science of the Total Environment, 407, 1536-1546.

Taylor, G. R., \& Butler, M. (1982). A comparison of the virucidal properties of chlorine, chlorine dioxide, bromine chloride and iodine. The Journal of Hygiene (Lond), 89, 321-328.

U.S. EPA (2000). Toxicological review of chlorine dioxide and chlorite (p. 6). Washington: U.S. Environmental Protection Agency; CAS Nos. 10049-04-4 and 7758-19-2.

WHO (2002). Guidelines for concentration and exposureResponse measurements of fine and ultra fine particulate matter for use in epidemiological studies. Geneva: World Health Organization.

Wilson, S. C., Wu, C., Andriychuk, L. A., Martin, J. M., Brasel, T. L., Jumper, C. A., et al. (2005). Effect of chlorine dioxide gas on fungi and mycotoxins associated with sick building syndrome. Applied and Environmental Microbiology, 71, 5399-5403. 